\title{
XLVIII. A report of the progress of vegetable physiology during the year 1836
}

\section{J. Meyen}

To cite this article: J. Meyen (1837) XLVIII. A report of the progress of vegetable physiology during the year 1836, Philosophical Magazine Series 3, 11:68, 381-390, DOI: $10.1080 / 14786443708649299$

To link to this article: http://dx.doi.org/10.1080/14786443708649299

册 Published online: 01 Jun 2009.

Submit your article to this journal $₫$

Џ Article views: 3

Q View related articles $\asymp$ 
adapted to measuring the deflecting forces of the galvanic battery. By using a thick wire it was ascertained that the calorimotor of Professor Hare having 40 plates, each 18 inches square, acted on the needle with a force equal to 92 grains, applied at the distance of 6 inches from the centre. In attempting to force the needle by torsion into a line parallel to the coil, where the deflecting current acts with the greatest strength, I accidentally carried it too far and reversed its position, when instantly it became reversed in polarity, that which had been the north pole becoming the south. This showed how unfit is the magnetic needle to measure such a quantity of electricity as was then flowing through the massive conductor. The instrument is well adapted to show to a class the experiments upon radiant heat with Pictet's conjugate reflectors, in which the differential or air thermometer affords, to spectators at a distance, but an unsatisfactory indication. For this purpose the electrical element necessary is merely a disk of bismuth as large as a shilling, soldered to a corresponding one of copper, blackened, and erected in the focus of the reflector, while conductors pass from each disk to the poles of the galvanometer. With this arrangement the heat of a non-luminous ball at the distance of 12 feet will impel the needle near $180^{\circ}$, and if the connexions and reversals are properly made will keep it in a continued revolution.

I have thus given you a brief sketch of an instrument which seems to supply a desideratum on the lecture-table, when the common thermometer is too small to afford to a class that direct and full satisfaction which, in a subject so important as that of heat, is very desirable to every professor. I have not so far attempted to use it extensively as an instrument of research, yet it shows evidently the importance of massiveness in conductors for feeble currents, such as those produced by thermo-combinations; nor am I certain that I have arrived at a maximum in this particular, for so far as I have proceeded in using thicker conductors for the coil the deflecting effects have been increased.

London, Aug. 30, 1837.

I am, \&c.

JoHN Locke.

XLVIII. A Report of the Progress of Vegetable Physiology during the Year 1836. By J. Meyen, Professor of Botany in the University of Berlin.*

I'T is delightful to see that during the past year not only have the works published in the province of botany been in.

* From Wiegmann's Archiv für Naturgeschichte, 1837, Part 3. Translated by Mr. Wm. Francis. 
creased in number, but the results of the labours recorded in them continue to become from year to year greater and more important. Systematic botany has received in the year which is past numerous and valuable contributions, for a whole series of most important works have appeared, not only on Phanerogamia, but also on Cryptogamia ; vegetable physiologv, also, has been enriched by a great amount of new data, and more correct views have been diffused in numerous publications upon many subjects, respecting which less accurate notions had heretofore been entertained. Nay, the number of works which appeared last year on subjects of physiological botany is so great that it is impossible in the small space allowed us to go fully into their contents, and it is more especially difficult to accomplish this with respect to the rich contents of some of the manuals which have appeared.

Several subjects of vegetable physiology which have been very fully treated of in former reports must also be now again noticed with greater minuteness: this perhaps might seem superfluous, but the object aimed at by the writer in these elaborate reports is to produce an unity in the views and an accordance in the observations and doctrines relative to the structure and functions of vegetables; so that this science may in the end become worthy to take its place by the side of animal physiology.

Great is the loss which the circle of botanists has sustained during the year which has terminated: Schrank, Persoon, Jussieu, and Schrader are no longer among them. Their labours are known, and will long impart lustre to the history of our science.

Since the first publication of this work (Wiegmann's Archiv) several yearly reports have appeared in Germany and in France, the contents of which more or less resemble ours. From the geographical position of Sweden, Wickström's year's report on the progress of botany must always reach us very late, and can never be so complete as if it had been prepared in the interior of the Continent; in order to remedy this defect Beilschmied has undertaken to translate those reports into German, and at the same time to enrich them with the most recent literature in which they are deficient. Thus last year we received Wickström's report for 1834*. A second volume of the Archives des Découvertes et Inventions nouvelles faites dans les Sciences, les Arts et les Manufactures tant en France que dans les Pays étrangers pendant l'année 1835+ has ap-

* Translated with additions and index by C.T. Beilschmied. Breslau, 1836.

$\uparrow$ Paris, 1836, 8vo. (An extrcmely poor picce of manufacture.-Wiegm.) 
peared; and Valentin of Berne* has given a critical view of the results of the principal physiological labours belonging to the year 1835; there is no want of competition, therefore, in works of this class, and it is only to be hoped that no one will go so far as to make up reports out of year's reports. The author of the present report designs to continue his labour in future years, and, circumstances permitting, will extend it to systematical botany also.

Convenient as it is to science that most of the learned societies now publish more or less copious notices of the labours of their menbers, it must still be remarked that short reports on the contents of several memoirs, read at the meetings of these societies, often appear in print, until at last, too frequently after a very long interval, the entire memoirs are published. Since however these short reports often contain but very incomplete statements, we have in many cases thought it necessary to wait the appearance of the original paper itself.

\section{On the Symmetry, Arrangement, and Characteristics of the Nature of Plants.}

The new edition of Link's Elementa Philosophia Botanica, which appeared last year, begins with the remark that natural bodies, when in a perfect state, possess a more or less symmetrical figure. In p. 30 he adduces proof that the entire plant or its parts are symmetrical, yet differing a little from exact symmetry. 'The plant is a compound organic body; each individual part is almost quite symmetrical, its combination however often not so, for many exterior circumstances hinder or accelerate the origin and growth of branches. A variation from the symmetrical form often takes place when superincumbent parts appear to retard complete development.

A small tract by Mohl $\uparrow$ treats more copiously on the symmetry of vegetables. It is there shown that nost organs of plants tend more or less evidently to symmetrical formation. The concentric, symmetrical, and the diaphorical mode of formation is in the first place distinguished, and then specially exemplified in a great number of plants. The structure of the lower order of plants is conceived extremely well, and the author observes that a correct notion of those plants in which stem and leaf are separated, can only be attained by a

- Vide Valentin's Repert. für Anat. und Physiol., \&c. Berlin, 1837, vol. i. p. $1-77$.

+ On the Symmetry of Plants (an Inaugural Dissertation). Tübingen, 1836, 8vo. 
comparison of them with the formation of the thallus in the lower plants. "We have seen," says he, p. 38, "according to what has been said, in the organs of vegetation a constant progression from the symmetrical to the concentric formation; not howevera fixed progression, but one interrupted by fluctuations. The pure symmetrical formation in the lower order of plants raised itself to the concentric on the stems of the Jungermannice and Lycopoclice; this however did not yet anpear openly, but still showed a considerableaffinity tothe symmetrical formation. In the Phanerogamia a weak tendency to the symmetrical formation is yet often evident in the stem; on the contrary, however, in general the most determined concentric organization shows itself; while in the leaves the symmetrical formation takes place in a manner not less remarkable than in the thallus of the Cryptogamia. In the branches we often observed a return to the symmetrical formation, while in the more highly developed leaf-forms many phænomena pointed to the tendency of the petiole of the leaf to raise itself to a concentric formation. We observed in the leaved stems and in the pinnate leaves the symmetry showing itself in a double form : first, in a narrow circle, in the corresponding formation of both side-halves of the individual leaflet; and secondly, in a wider circle, in the symmetrical formation of the two opposite leaflines sacrificing the symmetry of each individual leaflet."

In flowers it rarely occurs that they are not separated by a perpendicular section into two equal halves; and the general rule is that all terminal flowers are regular; that on the contrary irregular flowers are allotted to such inflorescences as are not terminal. According to this the symmetrical formation of the flowers stands in connection with their position.

Fries* has endeavoured to solve the question, which vegetables might be regarded as the most perfect, in a very ingenious manner. He first shows how the views of earlier botanists on this subject were untenable; he refutes most admirably De Candolle's view, according to which the Ranunculacea were the most perfect plants; for perfection in vegetables does not consist in the more perfect development of any individual organ, but in the harmonious development of all the organs collectively into a typical whole. Fries enumerates the following among the criteria of the perfection of a vegetable :

1. The greater number of degrees of metamorphosis a plant has to pass through, before the fruit is developed, the

- Essay towards a new answer to the question: Which vegetables are the most perfect? Transl. from the Swedish ly Hornschuch. Flora, 1836, p. $1-16$. 
more perfect it is. 2. The more complete the metamorphosis the more perfect is the vegetable. 3. The most perfect vegetables have also the most regular and symmetrical formation of the flower. 4. Those are the most perfect which not only possess all organs, but have these also combined in the most perfect harmony. 5. The greater stress nature has laid on the development of the seed, the more perfect is the plant. 6. Those vegetables are the most perfect which express in the purest manner by structure, form, numeral relations, and vital manifestations the type of their section. And, 7. since the typical form is the result of the most general relations, it follows from thence that the most perfect groups must be the most numerous and the greatest.

According to these fundamental positions, which in general are to be admitted, Fries pronounces the Compositce to be the most fully developed plants.

We have received some interesting observations on the generation of some of the lower $A \lg \mathscr{R}$, which continue to bring nearer to a decision the great question, whether the Bacillarica, and those beings nearly related to them, are to be classed under vegetables or animals. Mohl* first made known some observations on Conferva glomerata, according to which an increase of the members of this plant takes place by separation. The branches of this vegetable originate constantly on the end of the upper side of a member of the Conferva, and in such a manner that no communication takes place between the cells from which the branches originate and the inferior member of the branch, but both nembers are entirely separated by a septum. However, observations on branches just beginning to shoot show that at first this septum is wanting, and that there is present only a hook-like protuberance of the member, which grows in a cylindrical sac of about the common length of the members. A contraction then takes place, and appears in the form of a circular septum, pierced in the centre, which is gradually developed, till at last the connection between the cell of the branch and that of the stem is completely interrupted; and thus two cells entirely separated from each other have originated from the cell of the branch. The newly originated cell increases in size and again divides itself, \&c. In consequence of this observation, Mohl supposes that a similar mode of increase takes place also in the genera Scytonema and Oscillatoria; and in this we almost entirely agree with him. The same occurs also in the Rivu-

* On the Increase of the Cells of Plants by Separation. Tiibingen, 1835. (Published towards the end of 1836.)

Third Series. Vol. 11. No.68. Oct. 1837. $3 \mathrm{D}$ 
larice, although in this case the separation does not take place at the point of the sporangia, which however, as will be immediately shown, occurs also in Confervæ. From various phænomena it seemed probable to Mohl that in the several species also of the genus Spirogyra, Link, (Zygnema, Ag.), the single cells possess the property of dividing themselves in their centre by a septum. This supposition I can fully confirm; for experiments made on Spirogyra when budding (which since Vaucher's* observations it appears no one had repeated,) have shown it in a most evident manner. At the commencement in this case it is always the last member remaining in the burst capsule, which increases considerably in length, and divides itself by a new septum into two cells, upon which the inferior cell lengthens, \&c. Soon after some of these new cells lengthen and divide again.

These data, viz. the increase of the cells in microscopical plants by separation, are of great importance, and have hitherto been but rarely mentioned, and never with so much certainty. Carust formerly observed how the ends in Achyla prolifera Nees, separated by an apparent cellular septum from the other parts of the sac; Carus in the same memoir has also mentioned severalobservations on the gradual contractiondown to the complete separation. The origin of the fruit of the Vaucheria by constriction was also known; hitherto however no general conclusions on the growth of these plants by simple separation of the cells had been mentioned till Dumortier discovered a similar increase at the terminal cells of Conferva aurea $\neq$. As soon as the terminal cell of this Conferva had become considerably longer than the preceding members, a septum formed in its interior; this observation is quite similar to that of Mohl on Conferva glomerata. A similar mode of increase, viz. that by forming septa, was also observed by Morren $\oint$ in the Closterice, which this accurate naturalist is completely justified, by his very convincing reasons, in classing amongst vegetables, on which subject however we shall by and by have more to say.

It would now be of the greatest importance, if the datum, first confirmed by Dumortier, that cells can increase by $\mathbf{a}$ formation of septa, could also be demonstrated in the more perfect plants; this has been accomplished with tolerable certainty

- Hist. des Conferves. Pl. 4, 5 et 6.

$\dagger$ Nova Act. Acad. C. Nat. Cur., t. xi. p. 503.

1 Recherches sur la Structure comparée et le Développement des Ánimanx. et des Végétaux. Bruxelles, 1832, p. 10.

$\$$ Sur les Clostéries, Ann, des Scienc. Nat., vol. i. p. 274. 
by Mirbel's beautiful observations on the formation of the pollen in the Cucurbitacece. I myself have often thought I saw in the formation of the glandula capitate of several plants the origin of septa in the cells; the peculiarly formed hairs on the internal surface of the sacs in the genus Utricularia also appear to originate only by contraction, excrescence, and separation. Nay, even such a formation of more or less complete septa is evident in the diachymous cells of the leaves of Pinus silvestris; they may be seen in diagonal sections as runners from the internal side of the cellular septum; but a complete division of these cells is in truth not to be perceived.

An increase of vegetable cells by separation has been already proved in a direct manner; and therefore those distinctive characters which Ehrenberg* established between animals and vegetables are by no means so conclusive, but might on the contrary be used to prove what Ehrenberg endeavours to refute. Ehrenberg considers an increase by division as a character which belongs to numerous beings plainly evincing themselves to be animals, and which is totally wanting in plants, since the latter always grow by increasing in length and the formation of buds; and that on that account the Bacillarice are not plants, but must be classed with animals. As it has now been proved that the division of cells takes place exactly in the same manner in well-defined plants as in the Bacillaria, and as it can be shown that the separntion in the increase of Infusoria and other lower animals is very different from this separation of vegetable cells, such a separation by septa might even furnish a character to distinguish vegetables from animals.

Mohl $\dagger$ observes that the character mentioned by Ehrenberg, viz. the power of separation in animals, the want of it in plants, suffers the fate of various other distinctive characters which have been started separately : in general they are right, but in special and doubtful cases they are not to be depended on. Mohl here refers to his observation on the separation of the conferval sacs, of which we have already spoken. Mohl also confesses that after many year's' observation he still remains quite in doubt as to the place which the Bacillaria should occupy, that however their increasing by separation does not justify us in classing them as animals.

* Memoir read before the Academy of Berlin 25th of April. L'Institut, p. 195. Also Scientific Memoirs, vol. i. p. 405.

$\uparrow$ On a Character for distinguishing Animals and Plants proposed by Ehrenberg. Flora, 1836, vol. ii. p. 491-494. 
I may also mention that Link*, Ungert, and Morren + have of late remarked that these doubtful creatures which are known under the name of Bacillaria ought to be arranged with vegetables; according to this there would remain no other botanist, with the exception of Corda, that had paid any. considerable attention to vegetable anatomy who did not consider the Bacillarice to be plants.

From this we may judge of the contradictions on this subject, which are found in the reports edited by Wiegmann and myself on the progress of zoology and physiological botany for the year $1835 \oint$; as these creatures are at times mentioned as plants, at times as animals, and indeed under quite different denominations\|.

Morren, in the above-mentioned highly important memoir on the Closterice, has very fully treated the question whether they should be arranged with animals or vegetables; he succeeded, by employing very high magnifying powers, in showing that those red and very moveable little points discovered by Ehrenberg at the ends of these beings were nothing else than minute vesicles which afterwards change into new individuals. It was these moveable and as it were oscillating points which were considered as organs of motion, and appeared to justify the placing of the Closterice among animals, which however at present, after Morren's discovery, falls to the ground. Besides the occurrence of these self-moving propagula in the interior of the Closteria, Morren has observed a firmation of fruit by conjugation quite similar to the mode of formation of the fruit in the Conjugate ; and besides this, there also takes place an increase of the Closteria by separation.

The siliceous envelope which surrounds the Closteria as well as all other Bacillaria is regarded by Morren as a formation analogous to the so-called cuticula of plants, a fact which is capable of confirmation only in certain relations; for in the perfect plants this fine plate of silica lies in the substance of the

- Philos. Bot. Edit. alt., p. 400.

† Vide his treatise on Alge in Endlicher's Genera Plantarum.

\$ Sur les Clostéries, l. c. \$ Wiegmann's Archiv.

II I am sorry to say that these contradictions must also occur in this year's report; as I do not think Ehrenberg's view as to the animal nature of the Bacillaria weakened by the reasons here stated.-Wiegmann.

I The same observation has been already made by Corda and noticed by me in the report for the preceding year (1836, vol. ii. p. 186.). It had already been mentioned by Ehrenberg also in 1834. (Beitr. z. Kenntn. gr. Organis. in der Richtg. d. kl. Raumes, p. 95.)-Wiegmann. 
cuticula, and is only separated from this by the destruction of the organic parts. Besides this siliceous envelope Morren supposes the existence of two other distinct membranes, which form the cuticle of the Closterice and inclose the green substance; he howeyer remarks that they only become evident upon the metamorphosis of the plant. I consider the inner pellicle to be the analogue of the inner envelope which is formed in the members of Confervæ when their spores are ripened, or they begin to increase in any other nanuer, as for instance by excrescence and separation. Morren thinks it possible to explain the motion of the Closterice by the action of opposite electricities. The author also gives a very complete description, accompanied with drawings, of the very manifold forms which the Closteria exhibit at different periods; and by this he shows how at least six of the new species of the genus Closterium, described by Ehrenberg, belong to one and the same species.

De Brébisson* also made observations on the enignatical Diatomece in order to decide the question whether they should be classed with animals or vegetables. On burning a great number of Fragilaria pectinalis an animal smell was noticed. Such a smell would however be a very indefinite character, for various other Algæ produce a similar odour on their being burnt to a coal. After the burning of the Fragilaria pectinalis, and various other beings of the same kind, Brébisson found siliceous envelopes surrounding them in a very perfect state, and precisely similar to those exhibited by the fossil Diatomece discovered by C. Fischer in the peat-bog near Franzensbad, and which led to those beautiful observations that Ehrenberg made known on this subject in the course of last yeart. The results of those latter observations belong properly to geognosy; but we must add this one remark, that under the fossil Infusoria hitherto discovered, only those beings are to be understood which botanists, as has been previously shown, receive as plants. The occurrence in a fossil state of these minute microscopical plants is caused by the hard siliceous envelope, which resists all destroying influences. Kützing's discovery that the envelope of the Bacillaria consists of silica, which was mentioned in our first year's report, has by this circumstance been rendered more important. If we observe the same minute plants in the living state, it often happens that amongst them some dead ones occur, which ex-

- Observations sur les Diatomées.-L'Institut de 1836, p. 378.-Ann. des Scienc. Nat. 1836, ii. p. 248.

+ Vide On Fossil Infusoria, Wiegmann's Archiv, 1836, p. 333. A translation of Ehrenberg's two papers on this subject is given entire, and with engravings, in the Scientific Memoirs, vol. i. p. 400.-W. W. 
hibit that perfectly transparent and colourless siliceous envelope; it is therefore proved by this circumstance that a great mass of such siliceous envelopes might also be produced by the decomposition of the plants, or in the moist rway; and also that the mountain masses, which consist more or less of such siliceous envelopes, might not always be regarded as being produced by the action of heat at the bottom of the sea*. Brébisson tries to bring the Diatomea into two divisions, viz. the proper Diatomea, which exhibit a siliceous envelope, and the Desmidia, which are without a siliceous coating and entirely reduceable to carbon. In the more perfect plants, the epidermis of which is penetrated by a siliceous envelope, it would at least be improper to make such divisions; in this case, however, they may be of some use.

In a recent memoir Mohl $\uparrow$ has again declared himself against the animal nature of the Bacillaria. "I admit," says he, "that the doubt which was raised respecting their vegetable nature is not yet removed; their animal nature however has been as little proved, and we find evident transitions from them to vegetables, \&c.

[To be continued.]

XLIX. Notice relative to the Theory of the Winds. By JoHN Dalton, D.C.L., F.R.S.

\section{To Richard Taylor, Esq.}

Dear Friend, Manchester, Sept. 5th, 1837.

I PUBLISHED a theory of the Trade Winds, \&c., as Mr. 1 Dove has published + ,-it was forty-four years ago, as may be seen in my Meteorology, 1793 and 1834. It was first published by G. Hadley, Esq., in 1735, as I afterwards learnt. It is astonishing to find how the true theory should have stood out so long.

John Dalton.

L. Proceedings of Learned Societies.

\section{GEOLOGICAL SOCIE'TY.}

A LETTER addressed to C. Lyell, Esq. was then read from Dr. Mc A. Cleland, who has been associated with Mr.Griffith in the scientific deputation sent under Dr. Wallich into Upper Assam to investigate the natural history of the country where the tea-plant is found growing

* Ebrenberg's opinion is that these masses owe their origin to the action of volcanic heat on the bottom of the sea. Vide Scientific Memoirs, vol.i. p. 400.-W. F.

$\dagger$ On the Symmetry of Plants. Tübingen, 1836, in December. (Published as an Inaugural Dissertation.)

$\ddagger$ See our last and present Numbers. 